Historic, Archive Document

Do not assume content reflects current scientific knowledge, policies, or practices. 



\section{Northern Plant Novelties for 1930}

February 7, 1930

By Profesisor N. E. Hansen

Department of Horticulture, State College, Brookings, South Dakota

This Department does not conduct a commercial nurséry, but propagates and distributes new varieties originated in this department or imported from similar climates of the old world. In the work of originating new fruits more than 600,000 seedlings have been grown the past 34 years. The improvement in size and quality each plant generation is greater year by year. Hybridization and selection are the main methods of improvement. The varieties distributed so far are described in Bulletin 224. The work with hardy roses is described in Bulletin 240. The work with trees and shrubs is summarized in a bulletin nearly ready for the printer.

Terms: The money received from the sale of plants makes it possible to do the work on a larger scale than would otherwise be possible. Those who have followed the progress of the work for many years know the importance of ordering promptly, as soon as this list is received, as the supply of plants is limited. Terms are cash with order. No credit except to Government Experiment Stations.

Redflesh Crabapple: Good for the Lawn and for the Orchard

Introduced 1928. A most remarkable novelty, that is probably destined to world-wide popularity wherever apples are grown. The tree is ornamental as well as useful, the beautiful red flowers and moderate growth making it a very desirable lawn tree. The original tree gives promise of being a good annual bearer and bore its first two crops in 1927 and 1928. The fruit in size is $1 \frac{1}{2} \times 1 \frac{5}{8}$ inches in diameter, in color a brilliant solid polished dark red all over. The flesh is red throughout and makes excellent red preserves and red jelly which attracted favorable attention at the State College exhibit at the South Dakota State Fair, Huron, September, 1928. Season, fall. Pedigree: Pyrus Malus Niedzwetzkyana x Elk River, Minnesota, wild crab. The seed parent is from the Tian Shan Mountains that separate Russian Turkestan and western China. One-year old buds on Siberian crabapple stock. Each $\$ 1.00$.

\section{Sanoba Hybrid Sandcherry}

Introduced 1929. Pedigree: Sapa x Dropmore, Manitoba sandcherry. The name is made up from the two words, Sapa and Manitoba. The Sapa is my hybrid of the South Dakota sandcherry with a Japanese plum and is famous for its black-red flesh and choice quality. At Brookings, the Sanoba is a good plant; productive; of upright habit; fruit thirteensixteenths inch in diameter; fles' red; good quality; pit round and small. If the Sanoba inherits the extreme hardiness of the Manitoba sandcherry, it will be hardier than the Sapa and hence very popular in Manitoba and Saskatchewan. One-year old buds on native plum stock. Each \$1.00.

\section{Siberian Dewberry}

Offered for the first time. While sailing up the Irtysh River in Tomsk province, Siberia, in 1908, I noted with interest the many pailfuls of native dewberries brought to the steamer landings by the peasants. The fruit is roundish, small, black, with bluish bloom. Under cultivation on the open prairies here at Brooki,ıs the fruit, while of clear acid quality, has been too small to introduce as a market fruit. However, it may do 
better farther north. At any rate it is worthy of attention as the fruit can no doubt be increased in size by selection. The plant is hardy and productive. This is Seed and Plant Introduction No. 24377. From the steamer landing Katschiskaya. A few plants can be spared, each $\$ 1.00$.

\section{Ming Pear: A Good Hardy Pear for the Northwest}

Introduced 1917; named in 1927. I hope to have many more pear hybrids coming on in the future, but the Ming pear is worthy of trial right now. The original tree bore a heavy crop in 1926 and again in 1927. It has proven very resistant to fire blight. Pedigree: Pyrus Ovoidea $\mathrm{x}$ Louise Bonne de Jersey, a choice French pear. The fruit is of good commercial size, flesh melting, of delicious flavor, a first class pear. One-year trees, budded on Harbin pear seedlings, each $\$ 1.00$.

\section{PROGRESS WITH PEARS}

My opinion is that successful pear culture for home and market use is now possible for all South Dakota and the prairie Northwest, also for southern Manitoba and Saskatchewan. In 1924, I thought it would save fifty years of time by going to north Manchuria in the mountains along the railroad. I found the western limit of this northern type of Pyrus Ussuriensis to be about fifty miles east of Harbin, where the temperature ranges to about 47 degrees below zero. The fruit of this winter pear is about $2 \frac{1}{2}$ inches long and 2 inches across. The foliage is very ornamental in the fall due to the bright red and yellow color. I see no reason why it would not be a good shade tree for the lawn. It may be worth trying a few as a roadside or street tree.

The value of this type of pear is the strong resistance to the bacterial disease know as fire blight which kills the ordinary pear. From the seeds picked from the fresh fruit in 1924, I grew many thousands of trees in 1925. In 1926 most of them were transplanted in the State Orchard at Watertown. They have now grown four years and are ready for the final transplanting. The nurseryman should plant an orchard to provide hardy blight-resistant nursery stocks for the new hybrids now coming on. Pyrus Ussuriensis from the extreme southern part of Manchuria, did not prove hardy at Brookings.

Fire blight (Bacillus amylovorus) is native of the northeastern part of the United States, and is not native of Europe and Asia. (In Bulletin 237 , page 8 , line 29 , read "northeastorn" for "northwestern.")

I am now trying to find land for the final transplanting of the main bulk of these Harbin pears. It should be on state land where they can be left undisturbed for many years. Such an orchard would permit selection to be carried on and would be a permanent source of stocks upon which to bud or graft the new hybrids. Nurserymen would be willing to pay fair prices for hardy stocks of this kind. This would help support the work. An orchard of this kind should be state-owned because it goes beyond the lifetime of any private individual. It is an urgent matter because this seed was gathered at the far North, and such a strenuous tour of exploration cannot be made every year. The ordinary commercial Pyrus Ussuriensis seed is from sources much further south and such seedlings winter-kill at Brookings. Price of Harbin pear seedlings:

Size No. 1, Trees from 4 to 6 feet each \$1.25; No. 2, Trees from 3 to 4 feet each $\$ 1.00$; No. 3, Trees from 2 to 3 feet, each $75 \mathrm{c}$; No. 4 , Trees from 1 to 2 feet each $50 \mathrm{c}$.

\section{Pyrus Ovoidea Pear}

A hardy Chinese wild pear. Described in Bulletin 224. The bright red of the leaves in autumn is attractive. The fruit is one and five-eighths inches in diameter, sweet, juicy and of fair quality. One-year seedlings, 2 for $\$ 1.00$. 


\section{Seedling Crabapples}

Some one-year seedlings of the following crabapples are available. They will not come true to seed but some of them may produce better fruits; some may revert to Pyrus baccata. One-year seedlings of Beauty, Amur, Dolgo, Alexis, Mercer, not less than 10 of a kind. 10 for $\$ 1.00$.

\section{Elk River Wild Crab: A Dwarf Ornamental Lawn Tree}

Offered for the first time. Seedlings of Pyrus Ioensis from Elk River, about 40 miles north of Minneapolis, on the Mississippi River. Originally found by A. W. Keays. This makes a larger tree than the Nevis wild crab, but begins to bloom very early. The beautiful pink flowers are decidedly ornamental. One-year seedlings, 3 for $\$ 1.00$.

\section{Nevis Wild Crab: A Dwarf Ornamental Lawn Tree}

Offered for the first time. The wild American crabapple, Pyrus Ioensis, from the farthest northwestern point where it has been found native, Nevis, Minnesota, near the headwaters of the Mississippi River. Originally found by James Arrowood. A beautiful ornamental tree bearing when only four feet high, rich pink flowers in great profusion. One year seedlings, 3 for $\$ 1.00$.

\section{PROGRESS WITH GRAPES}

The 32 varieties introduced by N. E. Hansen in 1925 were widely distributed and are now in propagation. No plants for spring 1930; some cuttings can be spared, my selection, 5 cuttings for $\$ 1.00$.

\section{Siberian Perennial Sweet Pea}

Collected by N. E. Hansen in the dry Semipalatinsk region of Siberia in 1913, forms a long tuber; blossoms, bright pink color. An interesting novelty. Price, 2 tubers for 50c.

\section{Plums}

In propagating a set of new plums for the new orchard, we have none to offer in quantity. A few trees may be spared of the following varieties to help make up collections: Etopa, Tawena, Opata, Sapa, Wachampa, Cistena (red-leaved hybrid sandcherry), Waneta, Ezaptan, Cheresoto, Sansoto, Okiya. One-year buds or native plum stock. Each \$1.00.

\section{Sioux Sandcherry}

Described in Bulletin 224. This is still one of the best pure sandcherries in quality. Produced by selection. One-year buds on native plum stock. Each $\$ 1.00$.

\section{The Hansen Select Sandcherries}

Developed through nine plant generations from 300,000 seedlings of the native sandcherry, Prunus Besseyi, a low shrub of western South Dakota. In late years seedlings from Manitoba have been added. The seedlings vary in size and quality of fruit, but all are good for sauce or preserves. The white flowers and glossy leaves make it desirable as a low shrub in front of taller shrubs on the lawn. See Bulletin 224. Strong seedlings, five for $\$ 1.00$.

\section{The New State College Roses}

Many requests are received for my new roses described in South Dakota Bulletin 240. These are in propagation, chiefly by budding on seedlings of Semi rose, and I hope will be ready for next year's planting. A few sprouts from the original plants of some of these new roses can be dug for spring. Price, my selection, each \$1.00.

\section{Alika Rose}

Offered for the first time. Obtained by N. E. Hansen in Russia in the fall of 1896. Described in Bulletin 240. The name is adapted from the botanical name Rosa gallica grandiflora. Flowers large, fragrant, semi- 
double, with as high as 47 petals, with many stamens. Color brilliant red with no purple, mauve or violet red in it. It gets far away from the mauve pink of most of our wild prairie roses. A few plants on own roots can be spared. Each $\$ 1.50$.

\section{Mrs. Mina Lindell Rose}

Introduced 1927. A beautiful dwarf semi-double, light pink, wild rose found by Mrs. Mina Lindell in Butte county. To find a double wild rose on the prairies of South Dakota is indeed noteworthy. The piant sprouts freely so it will not be necessary to bud, graft, or grow from cuttings. A few plants on own roots can be spared. Each $\$ 1.00$.

\section{Ekta Rose}

Introduced 1927. Described in Bulletin 240 as follows: Pedigree: Rosa gallica grandiflora x American Beauty. Of tall upright habit; very hardy and vigorous. Flowers single, pink; blooming freely throughout June and a few days in July. Since the flowers are single this plant may not be a hybrid. However, the flowers are pink, while the flowers of the Rosa gallica parent are dark crimson. Also, it blooms earlier than Rosa gallica. This plant sprouts freely. May be useful for screens, hedges, or as an ornamental shrub. Rosa gallica is a native of central Europe extending east to the Caucausus mountains, has been cultivated "from time immemorial," and is regarded as one of the parents of the Hybrid Perpetuals. In the Island of Bourbon, France, it is customary to make hedges and palisades with the Bengal rose and Rosa gallica. Plants of Ekta Rose on own roots, each $\$ 1.00$.

\section{Semi Rose}

Introduced 1927. Described in Bulletin 240. The plants offered are grown from seed collected by N. E. Hansen on the dry steppes of Semipalatinsk, Siberia, in 1913. A strong growing shrub up to 8 feet in height and 13 feet across. Flowers small, white, blooming all summer, followed by long bright red fruits. In its present state this is chiefly of botanical value or for hedges and the shrub border. In England this species has been found useful as a budding stock; the budding must be done early in the season. Many of the seedlings have flowers pink instead of white. An endeavor is being made to separate the two types by co?or. Strong plants of Semi Rose, each $\$ 1.00$.

\section{Siberian Honeysuckles}

Young one-year seedlings of bush Honeysuckle with yellow or red berries, collected on the dry steppes at Semipalatinsk, Siberia, in 1913, by N. E. Hansen. 4 for $\$ 1.00$.

\section{PROGRESS WITH APPLES}

More work in taming and improving the wild American crabapple is being done at Brookings than anywhere else in the world. I am happy to report progress after thirty-four year of experiments in this line, and that the way to still greater success is quite apparent. Prominent among the new apples bred from the wild American crab, are the Anoka, the earliest and heaviest bearing of all apples; the Chinook crab, which keeps eighteen months; and the Redflesh crab, with red flowers, red fruit and red flesh. A lot more are on the way.

\section{PROGRESS WITH GOOSEBERRIES}

By crossing the native gooseberry of eastern South Dakota with the giant gooseberries of England, the largest gooseberries in the world, eleven excellent varieties have been secured. These are described in bulletin 224 . They have proven very productive under cultivaition. Lack of suitable land has prevented their more extensive propagation in recent years.

NOTE: The work with raspberries, strawberries and other small fruits is being postponed for the same reason: no.land. 